\title{
KEMAMPUAN KONEKSI MATEMATIS SIAPA YANG LEBIH TINGGI: GURU KELAS VERSUS GURU MATAPELAJARAN?
}

\section{WHO HAS HIGHER ABILITY OF MATHEMATICS CONNECTION : CLASS TEACHER VERSUS SUBJECT MATTER TEACHER?}

\author{
Ari Wibowo ${ }^{\text {a }}$, Hardi ${ }^{b}$ \\ ${ }^{a}$ Program Studi Pendidikan Guru Madrasah Ibtidaiyah FIT IAIN Surakarta \\ Jl. Pandawa Pucangan Kartasura Sukoharjo, aritmatika@gmail.com \\ ${ }^{b}$ Program Studi Pendidikan Guru Madrasah Ibtidaiyah FIT IAIN Surakarta \\ Jl. Pandawa Pucangan Kartasura Sukoharjo, hardi_sin@yahoo.com
}

\begin{abstract}
ABSTRAK
Salah satu pendekatan pembelajaran yang dapat dipilih oleh guru yang mengajarkan matematika pada kelas tinggi (kelas IV, V, dan VI) adalah dengan mengaitkan atau mengkoneksikan matematika. Koneksi matematis adalah keterkaitan antara topik matematika, keterkaitan antara matematika dengan disiplin ilmu lain, dan keterkaitan matematika dengan dunia nyata atau kehidupan sehari-hari. Pada penelitian ini dikaji kemampuan koneksi matematis yang dimiliki guru kelas tinggi pada topik aljabar yang diukur dengan soal kontekstual serta faktor yang mempengaruhinya. Populasi yang diteliti dalam penelitian ini adalah guru madrasah ibtidaiyah se-karesidenan Surakarta, baik negeri maupun swasta yang mengajar matematika pada kelas tinggi. Sedangkan sampel sejumlah 65 diambil secara acak dari populasi dengan menggunakan teknik penarikan sampel kluster. Teknik analisis statistika yang digunakan adalah statistika deskriptif dan eksploratif serta analisis regresi logistik ordinal. Pada kemampuan koneksi matematis dengan disiplin ilmu lain hampir separuh $(43,6 \%)$ guru kelas mampu menjawab pada level tertinggi (jawaban lengkap). Jumlah yang jauh lebih banyak jika dibandingkan dengan banyaknya guru matapelajaran/ mapel yang hanya kurang dari seperlimanya saja $(17,4 \%)$. Peubah penjelas yang dimasukkan kedalam model, yaitu peubah status guru (guru kelas dan guru mapel) tidak memberikan pengaruh yang signifikan terhadap level jawaban guru pada soal kemampuan koneksi matematis antar topik dan pada soal kemampuan koneksi matematis dengan dunia nyata atau kehidupan sehari-hari. Namun peubah penjelas status guru memberikan pengaruh yang signifikan terhadap level jawaban guru pada soal kemampuan koneksi matematis dengan disiplin ilmu lain. Berdasarkan hasil analisis regresi logistik ordinal diperoleh besar penduga rasio odds sebesar 0,275. Penduga odds bahwa jawaban guru kelas pada arah jawaban level rendah daripada arah jawaban level tinggi sebesar 0,275 kali penduga odds untuk guru mapel. Dengan demikian, jawaban guru kelas pada level rendah lebih sedikit jika dibandingkan jawaban guru mapel. Selanjutnya, berdasarkan selang kepercayaan $95 \%$ dari nilai rasio odds, dapat dijelaskan bahwa guru yang berstatus guru kelas mempunyai peluang lebih kecil (sebesar 0,103-0,734 kali), jika dibandingkan dengan guru berstatus guru mapel untuk menjawab pada level rendah, pada soal yang mengukur kemampuan koneksi matematis dengan disiplin ilmu lain.
\end{abstract}

Kata kunci: kemampuan koneksi matematis, status guru, guru madrasah ibtidaiyah

\begin{abstract}
One learning approach that can be chosen by teachers who teach mathematics in upper class (class IV, V, VI) is by correlating or connecting mathematics. Mathematics connection is correlation among mathematics topics, correlation among mathematics and other sciences, and correlation between mathematics and real life or daily life. In this research, it is studied mathematics connection ability of upper class teachers on aljabar topic that is measured by contextual questions and factors influencing them. The population in
\end{abstract}


this research is Islamic Elementary School teachers in Surakarta residency, either state or private, who teach mathematics in upper class. Meanwhile, the sample, 65, is taken randomly from the population by using cluster sample collection technique. The statistics analysis technique used is descriptive and explorative statistics and ordinal logistic regression analysis. In mathematics connection ability with other sciences, almost half (43.6\%) class teachers can answer at the highest level (complete answer). It is more than the number of subject matter teacher that is less than one-fifth (17.4\%). Explanatory variable which is included in this model is teacher status variable (class teacher and subject matter teacher). It doesn't influence significantly to teacher level in inter topic mathematics connection ability question and in mathematics connection ability question with real life or daily life. However, explanatory variable of teacher status influences significantly to teacher answer level in mathematics connection ability question with other sciences. Based on the result of ordinal logistic regression analysis, the estimated odds is 0.275 . The estimated odds that class teacher's answer is in low level answer, that is 0.275 times the estimated odds for subject matter teacher's answer. So, class teacher's answer in low level is less than subject matter teacher's answer. Next, based on confidence interval $95 \%$ of odds ratio value, it can be explained that class teacher has less probability $(0.103-0.734$ times $)$, than subject matter teacher to answer in low level, in questions measuring mathematics connection ability with other sciences.

Keyword: mathematics connection ability, teacher status, Islamic elementary school teachers

\section{Pendahuluan}

Metode atau pendekatan pembelajaran yang digunakan oleh seorang guru pada kegiatan belajar mengajar sangatlah penting. Guru harus dapat mencari metode yang tepat agar pelaksanaan pembelajaran dapat memperoleh hasil yang maksimal. Salah satunya dengan mengaitkan atau menkoneksikan materi pembelajaran dengan kehidupan yang nyata. Pada pembelajaran matematika pengkoneksian sangat dibutuhkan National Council of Teacher of Mathematics (NCTM) tahun 1989, koneksi matematika atau mathematical connections merupakan bagian yag sangat penting dalam pendidikan. Koneksi matematika adalah keterkaitan antara topik matematika, keterkaitan antara matematika dengan disiplin ilmu lain, dan keterkaitan matematika dengan dunia nyata atau kehidupan sehari-hari. Menurut Andi Gusmaulia Eka Putri (2018) kemampuan koneksi matematika peserta didik memiliki peran penting dalam proses pembelajaran matematika serta keberhasilan belajar peserta didik.

Koneksi matematis merupakan suatu keterampilan yang harus dibangun dan dipelajari oleh setiap guru maupun siswa. Dengan keterampilan yang dibangun maka guru maupun siswa dapat mencari hubungan-hubungan koneksi pada matematika. Dalam hal ini peranan koneksi matematika sangat penting untuk meningkatkan kemampuan menyelesaikan koneksi kontekstual atau soal kontekstual. Pemilihan konteks yang benar akan dapat meningkatkan pola pikir bagi peserta didik.

$$
\text { Pendidikan memiliki peran }
$$

penting dalam membangun sumber daya manusia yang kompetitif dan mampu 
bersaing dengan negara lain. Dalam menyongsong Masyarakat Ekonomi ASEAN (MEA), pendidikan harus mampu mempersiapkan sumber daya manusia yang terampil, peka dan kritis dalam menghadapi tantangan maupun perubahan-perubahan yang akan terjadi di dunia pendidikan mendatang. Menurut Ahmad Nizar Rangkuti (2017) agar guru matematika siap dalam menghadapi MEA, guru matematika harus memahami tentang isu-isu strategis, pengembangan keprofesian guru, dan revitalisasi pembelajaran matematika.

Kompetensi dasar matapelajaran Ilmu Pengetahuan Alam untuk kelas rendah (kelas I, II, dan III) pada kurikulum 2013 diintegrasikan dengan kompetensi dasar matapelajaran Bahasa Indonesia dan kompetensi dasar matapelajaran Matematika. Selain itu kompetensi dasar matapelajaran Ilmu Pengetahuan Sosial diintegrasikan ke kompetensi dasar matapelajaran Bahasa Indonesia, ke kompetensi dasar matapelajaran Pendidikan Pancasila dan Kewarganegaraan, dan ke kompetensi dasar matapelajaran Matematika. Sedangkan untuk kelas tinggi (kelas IV, $\mathrm{V}$, dan VI), kompetensi dasar matapelajaran Ilmu Pengetahuan Sosial dan Ilmu Pengetahuan Alam masingmasing berdiri sendiri, sehingga pendekatan integrasinya adalah multidisipliner, walaupun pembelajarannya tetap menggunakan tematik terpadu (mendikbud, 2013).
Karena alasan tersebut, kepala madrasah ibtidaiyah akan menunjuk guru dengan status guru kelas untuk mengajar di kelas rendah. Sedangkan untuk kelas tinggi, terdapat kepala sekolah yang menunjuk guru kelas untuk mengajarkan matapelajaran matematika, namun tidak jarang kepala sekolah yang menunjuk guru dengan status guru mapel (matapelajaran) untuk mengajarkan matapelajaran matematika.

Materi matapelajaran matematika pada kelas rendah di madrasah ibtidaiyah terintegrasi dengan matapelajaran IPA dan IPS, sehingga pada praktek pembelajarannya guru tidak leluasa untuk mengajarkan kemampuan koneksi matematis kecuali sesuai dengan tema yang diangkat pada pembelajaran tematik integratif. Menurut sudut pandang psikologis, pada kelas tinggi siswa sudah mulai mampu berpikir abstrak. Selain itu, karena pada kelas tinggi matapelajaran IPA dan IPS sudah berdiri sendiri maka pada matapelajaran matematika guru semakin leluasa untuk meningkatkan kemampuan koneksi matematis siswa. Satu hal yang sangat rasional adalah bagaimana mungkin guru bisa mengajarkan kemampuan koneksi matematis pada siswa jika kemampuan koneksi matematis yang dimiliki oleh guru masih rendah. Pada penelitian ini dikaji kemampuan koneksi matematis yang dimiliki guru kelas tinggi pada topik aljabar yang diukur dengan soal kontekstual. Selain itu dikaji pula 
pengaruh status guru dan gaya mengajar guru terhadap kemampuan koneksi matematis yang dimiliki oleh guru.

Tabel 1. Bentuk dan Indikator Kemampuan Koneksi Matematis

\begin{tabular}{|c|c|}
\hline No & $\begin{array}{c}\text { Bentuk dan Indikator } \\
\text { Kemampuan Koneksi } \\
\text { Matematis }\end{array}$ \\
\hline \multirow[t]{2}{*}{1} & $\begin{array}{l}\text { Bentuk: Mengenal dan menggu- } \\
\text { nakan hubungan antara topik } \\
\text { matematika. }\end{array}$ \\
\hline & $\begin{array}{l}\text { Indikator: Guru mampu } \\
\text { menuliskan ide-ide matematika } \\
\text { yang mendasari jawaban kemu- } \\
\text { dian menghubungkan dengan } \\
\text { ide baru atau topik lain }\end{array}$ \\
\hline \multirow[t]{2}{*}{2} & $\begin{array}{l}\text { Bentuk: Memahami keterkaitan } \\
\text { ide-ide matematika dan } \\
\text { membentuk ide satu dengan } \\
\text { yang lain sehinga } \\
\text { menghasilkan suatu keterkaitan } \\
\text { dengan ilmu lain }\end{array}$ \\
\hline & $\begin{array}{l}\text { Indikator: Guru mampu } \\
\text { membentuk keterkaitan ide-ide } \\
\text { matematika sehingga } \\
\text { menghasilkan suatu keterkaitan } \\
\text { yang menyeluruh dengan } \\
\text { disiplin ilmu lain }\end{array}$ \\
\hline \multirow[t]{2}{*}{3} & $\begin{array}{l}\text { Bentuk: Mengenal dan } \\
\text { menerapkan matematika dalam } \\
\text { kehidupan sehari-hari (nyata). }\end{array}$ \\
\hline & $\begin{array}{l}\text { Indikator: Guru mampu } \\
\text { mengkoneksikan antara } \\
\text { kejadian yang ada pada } \\
\text { kehidupan sehari-hari (nyata) } \\
\text { ke dalam model matematika dan } \\
\text { mencari jalan penyelesaiannya. }\end{array}$ \\
\hline
\end{tabular}

Dengan demikian, banyaknya responden sebesar 65 orang terdiri dari guru mapel dan guru kelas dengan perbandingan persentase masing-masing sebagaimana disajikan pada Gambar 1.

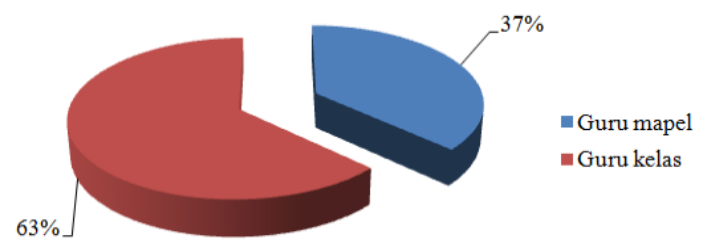

Gambar 1. Distribusi masing-masing responden berdasarkan status guru (guru mapel dan guru kelas)

Berdasarkan Gambar 1 tampak bahwa hampir dua pertiga guru yang diteliti adalah guru dengan status guru kelas. Sedangkan sekitar sepertiganya adalah guru dengan status guru mapel. Dengan demikian dapat disimpulkan bahwa guru yang mengajarkan matematika untuk kelas tinggi di MI sekaresidenan Surakarta sebanyak 63\% nya adalah guru kelas, sedangkan sisanya sebesar $37 \%$ adalah guru mapel dengan tingkat kepercayaan 95\% dan margin of error sebesar $12,16 \%$.

\section{Metode Penelitian}

Metode yang digunakan dalam penelitian ini adalah metode kuantitatif dengan menggunakan analisis data kategorik (categorical data analysis). Analisis data kategorik adalah analisis statistika yang digunakan ketika peubah respon atau variabel terikatnya berupa data kategori dengan skala pengukuran nominal atau ordinal. Saat ini penggunaan analisis data kategorik masih jarang digunakan di Indonesia. Hal tersebut dikarenakan penggunaan metode statistika untuk data kategorik tersebut baru meningkat pesat pada tahun 2007-an terutama pada bidang biomedis dan ilmu sosial (Agresti, 2007). Kesalahan yang 
saat ini masih sering terjadi adalah kesalahan seseorang dalam menggunakan metode statistika untuk data kontinu ketika mereka memiliki data kategorik.

Penelitian ini dilaksanakan di kabupaten dan kota se-karesidenan Surakarta, yang terdiri dari: kota Surakarta, kabupaten Sukoharjo, kabupaten Karanganyar, kabupaten Wonogiri, kabupaten Sragen, kabupaten Boyolali dan kabupaten Klaten. Alasan pemilihan tempat tersebut adalah karena mahasiswa IAIN Surakarta, khususnya program studi PGMI (Pendidikan Guru Madrasah Ibtidaiyah) mayoritas berasal dari kabupaten dan kota tersebut. Salah satu manfaat temuan penelitian ini adalah untuk memberi masukan bagi para pengambil keputusan di tingkat program studi, fakultas ataupun institut untuk menjawab kebutuhan pangsa pasar dari program studi PGMI, khususnya pada mata kuliah ke PGMI-an misalnya mata kuliah matematika. Hal tersebut karena bagaimanapun tujuan utama didirikannya program studi PGMI adalah untuk mencetak calon tenaga pengajar di madrasah ibtidaiyah di sekitar mereka tinggal. Penelitian ini dilaksanakan pada bulan April sampai dengan Oktober tahun 2018.

Populasi yang diteliti dan menjadi pusat perhatian dalam penelitian ini adalah guru madrasah ibtidaiyah sekaresidenan Surakarta, baik negeri maupun swasta yang mengajar matematika pada kelas tinggi (Kelas IV,
V, dan VI). Sedangkan sampel pada penelitian ini adalah guru yang merepresentasikan guru madrasah ibtidaiyah se-karesidenan Surakarta, baik negeri maupun swasta yang mengajar matematika pada kelas tinggi (Kelas IV, V, dan VI).

Teknik sampling atau teknik pengambilan sampel yang digunakan dalam penelitian ini adalah dengan menggunakan teknik probability sampling. Teknik tersebut adalah teknik pengambilan sampel dengan memberikan peluang yang sama bagi setiap unsur (anggota) populasi untuk dipilih menjadi anggota sampel. Dalam penerapannya, teknik probability sampling dilakukan dengan cara cluster sampling dengan langkah-langkah sebagai berikut: (a) karena masing-masing kabupaten dan kota terdiri dari kecamatan-kecamatan maka langkah awal pengambilan sampel adalah populasi terlebih dahulu dikelompokan menjadi sub-sub populasi dengan kriteria yang sama. Sub populasi dari masingmasing kabupaten dan kota berupa kecamatan-kecamatan yang terletak di kabupaten dan kota tersebut, (b) langkah selanjutnya adalah memilih secara acak satu kecamatan dari masing-masing subpopulasi, (c) setelah diperoleh satu kecamatan yang mewakili masing-masing sub populasi, langkah selanjutnya adalah mendata keseluruhan madrasah ibtidaiyah pada masing-masing kecamatan tersebut, baik madrasah ibtidaiyah negeri maupun swasta, dan (d) langkah terakhir adalah 
mengambil keseluruhan guru yang mengajar mata pelajaran pada kelas tinggi (kelas IV, V, dan VI).

Penelitian ini menggunakan data kuantitatif yang dikumpulkan melalui tes. Tes yang digunakan berupa tes kontekstual berbentuk tes essei untuk mengukur tiga kemampuan koneksi matematis, yaitu koneksi matematis antar topik, koneksi matematis dengan disiplin ilmu lain, dan koneksi matematis dengan dunia nyata atau kehidupan sehari-hari. Tes essei tersebut disajikan pada Tabel 2.

Tabel 2. Soal Kontekstual Untuk Mengukur Kemampuan Koneksi Matematis

Soal Kontekstual Pada Masing-masing Kemampuan Koneksi Matematis

1. Koneksi matematis antar topik

Soal: Sebuah kawat panjangnya $16 \mathrm{~cm}$ akan dibuat persegi panjang. Buatlah persegi panjang-persegi panjang tersebut dan hitung masing masing luasnya dari persegi panjang tersebut! (Keterangan: ukuran panjang dan lebar persegi panjang yang boleh dibuat dibatasi bilangan bulat positif)

2. Koneksi matematis dengan disiplin ilmu lain

Soal: Dua kapal laut yaitu A dan B berlayar dengan waktu yang sama dan tempat yang sama. Kapal A berlayar ke utara dengan kecepatan $15 \mathrm{~km} / \mathrm{jam}$, sedangkan kapal B berlayar ke barat dengan kecepatan $20 \mathrm{~km} / \mathrm{jam}$. Setelah 2 jam keduanya berhenti karena kapal A rusak, maka kapal $\mathrm{B}$ harus menyusulnya. Berapakah waktu yang dibutuhkan kapal B menuju kapal A?

3. Koneksi matematis dengan dunia nyata atau kehidupan sehari-hari.

Soal: Pemilik bengkel mendapatkan order untuk memperbaiki mobil yang habis kecelakaan. Biaya yang disepakati adalah Rp. 12.500.000. Untuk perbaikan mobil tersebut mengeluarkan biaya;
Untuk tukang las $12 \%$, Untuk beli cat $15,5 \%$ dan bahan lainya $26 \%$. Berapa rupiahkah pemilik bengkel tersebut mendapatkan penghasilan bersih?

Rubrik penskoran untuk masingmasing soal terdiri dari 4 level jawaban sebagaimana disajikan pada Tabel 3.

Tabel 3. Level Jawaban Guru beserta Keterangannya

\begin{tabular}{cc}
\hline $\begin{array}{c}\text { Level Jawaban } \\
\text { Guru }\end{array}$ & Keterangan \\
\hline 4 & Jawaban lengkap \\
3 & $\begin{array}{c}\text { Jawaban kurang } \\
\text { lengkap } \\
\text { Jawaban hanya } \\
\text { sebagian } \\
2\end{array}$ \\
1 & $\begin{array}{c}\text { Hanya sekedar } \\
\text { menjawab }\end{array}$ \\
\hline
\end{tabular}

Hasil dan Pembahasan

Madrasah Ibtidaiyah Se-Karesidenan Surakarta

Populasi yang menjadi pusat perhatian pada penelitian ini adalah guru Madrasah Ibtidaiyah (MI) yang mengajarkan mata pelajaran matematika pada kelas tinggi, yaitu kelas 4, 5 dan 6 dikaresidenan Surakarta. Karesidenan Surakarta sendiri terdiri dari satu kota dan enam kabupaten. Satu kota tersebut adalah kota Surakarta, sedangkan enam kabupaten terdiri dari kabupaten:

Boyolali, (2) Karanganyar, (3) Klaten, (4) Sragen, (5) Sukoharjo, dan

Wonogiri. Dengan demikian, karena masing-masing kabupaten dan kota terdiri dari kecamatan-kecamatan maka langkah awal pengambilan sampel adalah populasi terlebih dahulu dikelompokan menjadi 
sub-sub populasi dengan kriteria yang sama. Sub populasi dari masing-masing kabupaten dan kota berupa kecamatankecamatan yang terletak di kabupaten dan kota tersebut. Banyaknya kecamatan yang terletak pada kabupaten dan kota tersebut disajikan pada Gambar 2.

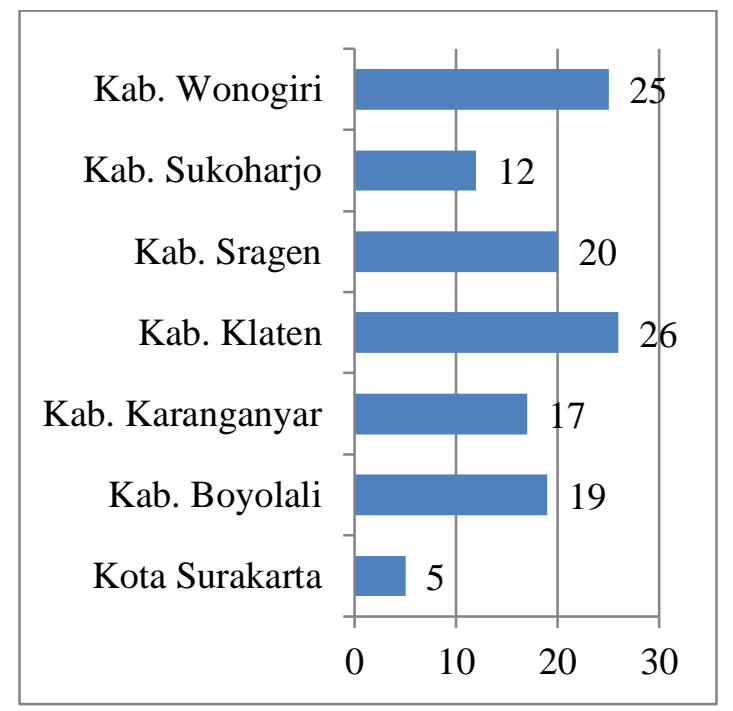

Gambar 2. Diagram Batang Banyaknya Kecamatan di Kabupaten dan Kota SeKaresidenan Surakarta

Berdasarkan Gambar 2 tampak bahwa kabupaten dengan kecamatan paling banyak adalah kabupaten Klaten dan Wonogiri yang masing-masing memiliki 26 dan 25 kecamatan. Sedangkan kota Surakarta memiliki kecamatan yang paling sedikit, yaitu sebanyak 5 kecamatan.

Setelah kita memperoleh namanama kecamatan yang terletak di kabupaten dan kota, langkah untuk menentukan sampel selanjutnya adalah mengambil secara acak satu kecamatan yang mewakili kabupaten dan kota tersebut. Kemudian langkah selanjutnya adalah mengambil seluruh MI, baik Negeri maupun Swasta yang terletak pada satu kecamatan yang telah terpilih pada masing-masing kabupaten dan kota. Banyaknya MI Negeri dan Swasta sekaresidenan Surakarta adalah 576, yang terdistribusi pada satu kota dan 6 kabupaten sebagaimana disajikan pada Tabel 4.

Tabel 4. Distribusi MI Negeri dan Swasta Se-Karesidenan Surakarta

\begin{tabular}{|c|c|c|c|c|}
\hline \multirow{2}{*}{$\begin{array}{l}\mathrm{N} \\
\mathrm{o}\end{array}$} & \multirow{2}{*}{$\begin{array}{c}\text { Kabupaten/ } \\
\text { Kota }\end{array}$} & \multicolumn{2}{|c|}{ Banyaknya MI } & \multirow{2}{*}{$\begin{array}{l}\text { To- } \\
\text { tal }\end{array}$} \\
\hline & & $\underset{i}{\text { Neger }}$ & $\begin{array}{c}\text { Swast } \\
\text { a }\end{array}$ & \\
\hline 1 & $\begin{array}{l}\text { Kota } \\
\text { Surakarta }\end{array}$ & 1 & 7 & 8 \\
\hline 2 & $\begin{array}{l}\text { Kab. } \\
\text { Boyolali }\end{array}$ & 12 & 194 & $\begin{array}{c}20 \\
6\end{array}$ \\
\hline 3 & $\begin{array}{l}\text { Kab. } \\
\text { Karanganya } \\
r\end{array}$ & 3 & 66 & 69 \\
\hline 4 & Kab. Klaten & 3 & 80 & 83 \\
\hline 5 & Kab. Sragen & 9 & 65 & 74 \\
\hline 6 & $\begin{array}{l}\text { Kab. } \\
\text { Sukoharjo }\end{array}$ & 6 & 75 & 81 \\
\hline 7 & $\begin{array}{l}\text { Kab. } \\
\text { Wonogiri }\end{array}$ & 2 & 53 & 55 \\
\hline & Jumlah & 36 & 540 & $\begin{array}{c}57 \\
6\end{array}$ \\
\hline
\end{tabular}

Sumber: referensi.data.kemdikbud.go.id

Berdasarkan Tabel 4 tampak bahwa MI negeri dan swasta terbanyak terdapat di kabupaten Boyolali yaitu lebih dari 200 madrasah. Banyaknya MI negeri dan swasta di kabupaten tersebut lebih dari dua kali lipat banyaknya MI negeri dan swasta di kabupaten-kabupaten yang lain yang terletak di-karesidenan Surakarta. Selain itu tampak bahwa di kabupaten-kabupaten se-karesidenan Surakarta selain kabupaten Boyolali memiliki MI negeri dan swasta yang jumlahnya relatif sama, yaitu tidak sampai 100 madrasah. Sedangkan banyaknya MI 
negeri dan swasta di kota Surakarta sangat sedikit, hanya sebanyak 8 madrasah saja. Secara keseluruhan, persentase banyaknya MI, baik MI negeri maupun swasta pada masing-masing kabupaten/ kota dapat dilihat pada Gambar 3.

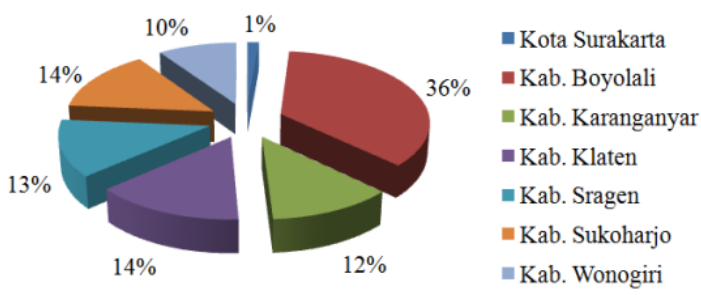

Gambar 3. Diagram Lingkaran Banyaknya MI Se-Karesidenan Surakarta

Berdasarkan Gambar 3 tampak bahwa lebih dari sepertiga MI negeri maupun swasta di-karesidenan Surakarta terletak di kabupaten Boyolali. Sedangkan banyaknya MI di kabupaten-kabupaten lain hanya berkisar $10 \%$ sampai dengan 14\%. Selain itu tampak bahwa banyaknya MI yang terletak di kota Surakarta sangat sedikit, yaitu hanya sebesar $1 \%$ saja.

Banyaknya MI yang terpilih sebagai sampel secara keseluruhan adalah sebanyak 32 madrasah. Ke-32 madrasah tersebut terpilih dari populasi sebanyak 576 madrasah. Dengan demikian persentase banyaknya MI yang terpilih sebagai sampel adalah sebesar 5,56\%. Pada Tabel 5 disajikan distribusi banyaknya MI yang terpilih menjadi sampel dan persentasenya pada masingmasing kabupaten dan kota sekaresidenan Surakarta.
Tabel 5. Distribusi MI yang Terpilih Sebagai Sampel

\begin{tabular}{|c|c|c|c|c|}
\hline \multirow[b]{2}{*}{$\begin{array}{l}\mathrm{N} \\
\mathrm{O}\end{array}$} & \multirow{2}{*}{$\begin{array}{c}\text { Kabupaten/ } \\
\text { Kota }\end{array}$} & \multicolumn{2}{|c|}{$\begin{array}{c}\text { Banyaknya } \\
\text { MI Pada }\end{array}$} & \multirow{2}{*}{$\begin{array}{c}\text { Persen- } \\
\text { tase } \\
\text { Sampel }\end{array}$} \\
\hline & & $\begin{array}{c}\text { Pop } \\
\mathrm{u}- \\
\text { lasi }\end{array}$ & $\begin{array}{l}\text { Sam } \\
\text {-pel }\end{array}$ & \\
\hline 1 & $\begin{array}{l}\text { Kota } \\
\text { Surakarta }\end{array}$ & 8 & 2 & $25 \%$ \\
\hline 2 & $\begin{array}{l}\text { Kab. } \\
\text { Boyolali } \\
\text { Kab. }\end{array}$ & 206 & 6 & $2,91 \%$ \\
\hline 3 & $\begin{array}{l}\text { Karanganya } \\
\mathrm{r}\end{array}$ & 69 & 3 & $4,35 \%$ \\
\hline 4 & Kab. Klaten & 83 & 2 & $2,41 \%$ \\
\hline 5 & Kab. Sragen & 74 & 6 & $8,11 \%$ \\
\hline 6 & $\begin{array}{l}\text { Kab. } \\
\text { Sukoharjo }\end{array}$ & 81 & 8 & $9,88 \%$ \\
\hline 7 & $\begin{array}{l}\text { Kab. } \\
\text { Wonogiri }\end{array}$ & 55 & 5 & $9,09 \%$ \\
\hline & Total & 576 & 32 & $5,56 \%$ \\
\hline
\end{tabular}

Berdasarkan Tabel 5 tampak distribusi 32 MI yang terambil dari 576 MI yang terletak di kabupaten dan kota sekaresidenan Surakarta. Secara keseluruhan, banyaknya MI yang digunakan sebagai sampel pada penelitian ini adalah sebesar 5,56\%.

\section{Guru Kelas Versus Guru Mapel Pada Madrasah Ibtidaiyah Se-Karesidenan Surakarta}

Selanjutnya langkah terakhir dalam menentukan responden pada penelitian ini adalah mengambil semua guru yang mengajarkan matematika pada kelas tinggi (kelas 4, 5, dan 6) di 32 madrasah tersebut. Berdasarkan data yang diperoleh dari lapangan, diperoleh informasi bahwa guru yang mengajarkan matematika pada kelas tinggi terdiri dari dua kelompok, yaitu kelompok guru mata 
pelajaran (mapel) dan kelompok guru kelas. Distribusi banyaknya responden, baik yang berstatus sebagai guru mapel maupun guru kelas pada masing-masing kecamatan yang terpilih sebagai sampel disajikan pada Tabel 6 .

Tabel 6. Distribusi Banyaknya

Responden Pada Masing-masing Kecamatan

\begin{tabular}{|c|c|c|c|c|}
\hline \multirow{2}{*}{$\begin{array}{l}\mathrm{N} \\
\mathrm{O}\end{array}$} & \multirow{2}{*}{$\begin{array}{c}\text { Sampel } \\
\text { Kecamatan } \\
\text { (Populasi) }\end{array}$} & \multirow{2}{*}{$\begin{array}{c}\text { Banyak } \\
\text { Respon } \\
\text {-den }\end{array}$} & \multicolumn{2}{|c|}{$\begin{array}{l}\text { Status } \\
\text { Guru }\end{array}$} \\
\hline & & & $\begin{array}{l}\text { Ma- } \\
\text { pel }\end{array}$ & $\begin{array}{l}\mathrm{Ke}- \\
\text { las }\end{array}$ \\
\hline 1 & $\begin{array}{l}\text { Banjarsari } \\
\text { (Surakarta) }\end{array}$ & 11 & 0 & 11 \\
\hline 2 & $\begin{array}{l}\text { Banyudono } \\
\text { (Boyolali) }\end{array}$ & 16 & 2 & 14 \\
\hline 3 & $\begin{array}{l}\text { Kebakkramat } \\
\text { (Karanganyar } \\
\text { ) }\end{array}$ & 3 & 3 & 0 \\
\hline 4 & $\begin{array}{l}\text { Wonosari } \\
\text { (Klaten) }\end{array}$ & 3 & 0 & 3 \\
\hline 5 & $\begin{array}{l}\text { Sumberlawan } \\
\mathrm{g} \text { (Sragen) }\end{array}$ & 7 & 7 & 0 \\
\hline 6 & $\begin{array}{l}\text { Kartasura } \\
\text { (Sukoharjo) }\end{array}$ & 14 & 12 & 2 \\
\hline 7 & $\begin{array}{l}\text { Wonogiri } \\
\text { (Wonogiri) }\end{array}$ & 11 & 0 & 11 \\
\hline & Jumlah & 65 & 24 & 41 \\
\hline
\end{tabular}

Berdasarkan Tabel 6 tampak bahwa banyaknya keseluruhan responden yang digunakan dalam penelitian ini adalah 65 responden dengan tingkat kepercayaan $95 \%$ dan margin of error sebesar $12,16 \%$. Pada tabel tersebut juga tampak adanya perbedaan distribusi guru mapel dan guru kelas pada masing-masing kecamatan yang mewakili kabupaten dan kota se-karesidenan Surakarta. Agar mudah memperoleh informasi tentang distribusi guru mapel dan guru kelas pada Gambar 4 disajikan diagram batang dari distribusi tersebut.

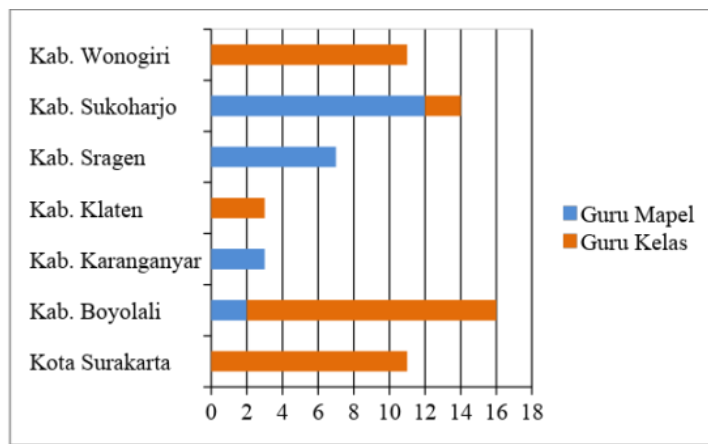

Gambar 4. Distribusi Guru Mapel dan Guru Kelas Pada Masing-masing Kabupaten dan Kota Se-Karesidenan Surakarta

Informasi yang dapat diperoleh dari Gambar 4 adalah bahwa keseluruhan responden yang berasal dari kota Surakarta, kabupaten Klaten dan kabupaten Wonogiri adalah guru kelas. Keseluruhan responden yang berasal dari kabupaten Karanganyar dan kabupaten Sragen adalah guru mapel. Sedangkan mayoritas responden yang berasal dari kabupaten Boyolali adalah guru kelas, namun mayoritas responden yang berasal dari kabupaten Sukoharjo adalah guru mapel.

\section{Tiga Kemampuan Koneksi Matematis} Guru MI Se-Karesidenan Surakarta

Persentase masing-masing level jawaban guru pada ketiga kemampuan koneksi matematis, yaitu kemampuan koneksi matematis antar topik, kemampuan koneksi matematis dengan disiplin ilmu lain dan kemampuan koneksi matematis dengan dunia nyata atau kehidupan sehari-hari disajikan pada Gambar 5. 


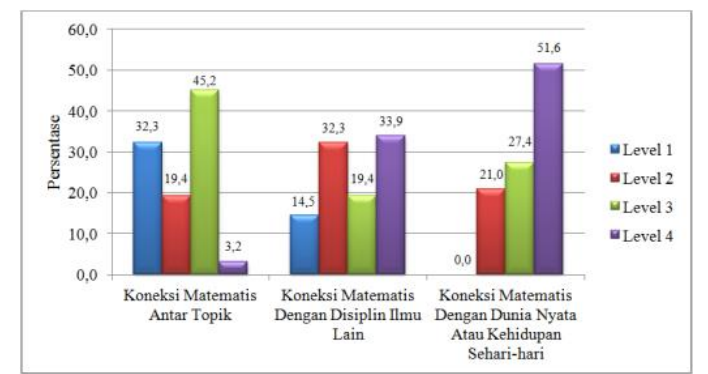

Gambar 5 Persentase Masing-Masing Level Jawaban Guru Pada Ketiga Kemampuan Koneksi Matematis

Berdasarkan Gambar 5 tampak bahwa hampir tidak ada guru (hanya kurang dari 4\%) yang mampu menjawab pada level 4 (jawaban lengkap) pada soal kemampuan koneksi matematis matematis antar topik dari total 62 guru MI. Sedangkan hampir separuh $(45,2 \%)$ mampu menjawab pada level 3 (jawaban kurang lengkap). hanya 3,2\% yang mampu menjawab pada level 4 (jawaban lengkap). Pada soal kemampuan koneksi matematis matematis dengan disiplin ilmu lain tampak sekitar sepertiga mahasiswa masing-masing mampu menjawab pada level 2 (jawaban hanya sebagian) dan level 4 (jawaban lengkap). antar topik dari total 62 guru MI. Sedangkan pada soal koneksi matematis dengan dunia nyata atau kehidupan sehari-hari tampak sekitar separuh $(51,6 \%)$ mampu menjawab pada level 4 (jawaban lengkap).

Apabila kemampuan koneksi matematis antar topik ditinjau berdasarkan status guru (guru kelas dan guru mapel) persentase yang mampu menjawab pada masing-masing level disajikan pada Gambar 6.

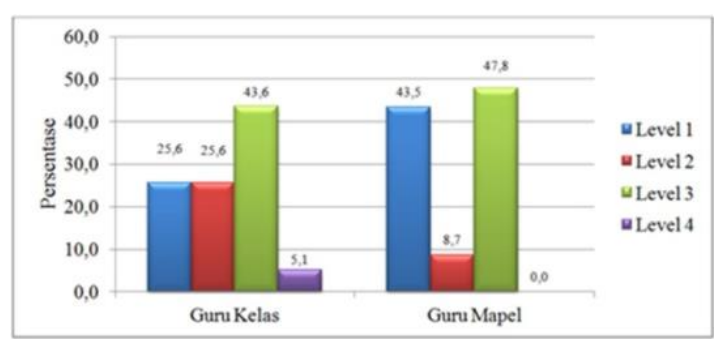

Gambar 6. Persentase Level Jawaban Guru Pada Kemampuan Koneksi Matematis Antar Topik

Berdasarkan Gambar 6 tampak kesamaan kemampuan koneksi matematis antar topik pada kelompok guru kelas dan guru mapel adalah sangat sedikit sekali atau bahkan tidak ada sama sekali guru yang mampu menjawab pada level 4 (jawaban lengkap). Perbedaannya tampak pada banyaknya guru yang hanya mampu menjawab pada level 2 ((jawaban hanya sebagian). Pada guru kelas sebanyak seperempat guru hanya mampu menjawab pada level 2, sedangkan pada guru mapel hanya kurang dari sepersepuluh. Selain itu perbedaan tampak pada guru yang mampu menjawab pada level 1 (hanya sekedar menjawab). Pada guru kelas ditemukan sekitar seperempat mahasiswa $(25,6 \%)$ hanya sekedar menjawab, namun pada guru mapel ditemukan jumlahnya hampir mencapai separuh $(43,5 \%)$.

Apabila kemampuan koneksi matematis dengan disiplin ilmu lain ditinjau berdasarkan status guru (guru kelas dan guru mapel) persentase yang mampu menjawab pada masing-masing level disajikan pada Gambar 7. 


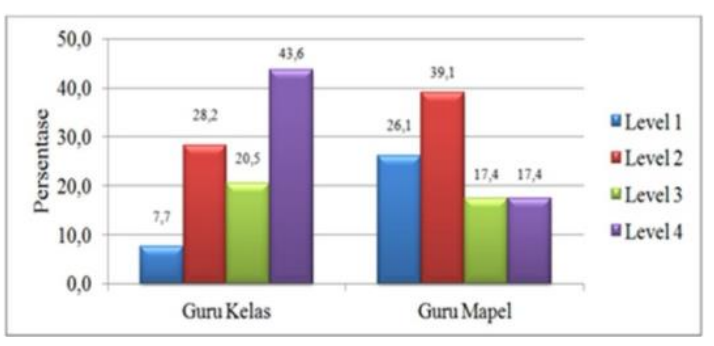

Gambar 7. Persentase Level Jawaban Guru Pada Kemampuan Koneksi Matematis Dengan Disiplin Ilmu Lain

Berdasarkan Gambar 7 tampak perbedaan kemampuan koneksi matematis dengan disiplin ilmu lain pada kelompok guru kelas dan guru mapel. Pada kelompok guru kelas ditemukan kurang dari sepersepuluh $(7,7 \%)$ yang hanya asal menjawab (level 1), namun pada guru mapel ditemukan lebih banyak yaitu sekitar seperempatnya $(26,1 \%)$ yang hanya asal menjawab. Selain itu tampak bahwa hampir separuh $(43,6 \%)$ guru kelas mampu menjawab dengan lengkap (level 4). Jumlah tersebut jauh lebih banyak jika dibandingkan dengan guru mapel yang mampu menjawab dengan lengkap (level 4) hanya kurang dari seperlimanya saja $(17,4 \%)$.

Apabila koneksi matematis dengan dunia nyata atau kehidupan seharihari ditinjau berdasarkan status guru (guru kelas dan guru mapel) persentase yang mampu menjawab pada masing-masing level disajikan pada Gambar 8.

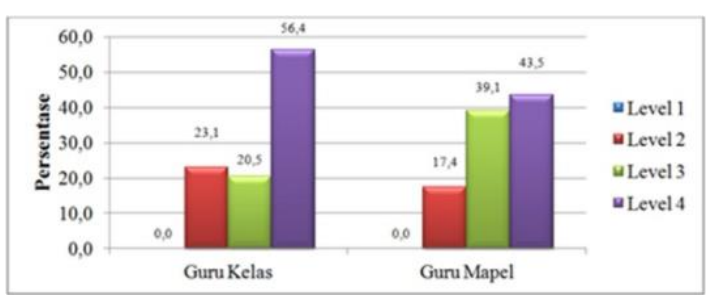

Gambar 8. Persentase Level Jawaban Guru Pada Kemampuan Koneksi

\section{Matematis Dengan Dunia Nyata Atau Kehidupan Sehari-hari}

Berdasarkan Gambar 8 tampak persamaan kemampuan koneksi matematis dengan dunia nyata atau kehidupan sehari-hari antara guru kelas dan guru mapel tidak ditemukan sama sekali guru hanya asal menjawab (level 1). Selain itu persamaannya adalah mayoritas guru kelas dan guru mapel mampu menjawab dengan lengkap (level 4) masing-masing sebesar 56,4\% dan 43,5\%. Perbedaan kemampuan koneksi matematis dengan dunia nyata atau kehidupan sehari-hari pada kelompok guru kelas dan guru mapel adalah banyaknya guru yang mampu menjawab kurang lengkap (level 3). Pada guru kelas ditemukan seperlima (20,5\%) guru mampu menjawab pada level tersebut, namun pada guru mapel ditemukan jumlah yang lebih banyak, yaitu sebanyak lebih dari sepertiga $(39,1 \%)$.

\section{Pengaruh Status Guru Terhadap}

\section{Kemampuan Koneksi Matematis}

\section{Pertama}

Regresi logistik ordinal digunakan untuk mengkaji pengaruh status (guru kelas dan guru mapel) terhadap level jawaban guru pada kemampuan koneksi matematis antar topik. Dengan menggunakan prosedur Tabulate yang tersedia dalam SAS (Statistical Analysis System) versi 9.0.0, dibuatlah tabel data level jawaban guru pada soal yang mengukur kemampuan koneksi matematis 
antar topik sebagaimana tampak pada

Tabel 7.

Tabel 7. Level Jawaban Guru Pada

Kemampuan Koneksi Matematis Dengan Disiplin Ilmu Lain

\begin{tabular}{|c|c|c|c|c|c|}
\hline \multirow{2}{*}{$\begin{array}{l}\text { Status } \\
\text { Guru }\end{array}$} & \multicolumn{4}{|c|}{ Level Jawaban Guru } & \multirow{2}{*}{$\begin{array}{l}\text { To- } \\
\text { tal }\end{array}$} \\
\hline & 1 & 2 & 3 & 4 & \\
\hline Guru kelas & 10 & 10 & 17 & 2 & 39 \\
\hline $\begin{array}{c}\text { Guru } \\
\text { mapel }\end{array}$ & 10 & 2 & 11 & 0 & 23 \\
\hline
\end{tabular}

Berdasarkan Tabel 7 tampak bahwa hampir semua guru berstatus guru mapel yang mengajar matematika pada kelas tinggi tidak mampu menyelesaikan soal koneksi matematis antar topik. Hanya 2 orang guru berstatus guru kelas dari total 39 guru kelas yang mampu menjawab soal tersebut dengan jawaban lengkap. Sedangkan semua guru berstatus guru mapel yang mengajar matematika pada kelas tinggi tidak mampu menyelesaikan soal koneksi matematis antar topik. Tidak ada satu pun guru berstatus status guru kelas dari total 23 guru kelas yang mampu menjawab soal tersebut dengan jawaban lengkap.

Hasil uji kelayakan model pada analisis regresi logistik ordinal dengan menggunakan SAS versi 9.0.0 dapat dilihat pada Tabel 8.
Tabel 8. Hasil uji kelayakan model dengan peubah penjelas

\begin{tabular}{lccc}
\hline Kriteria & Nilai & df & Nilai-p \\
\hline Deviance & 5,7143 & 3 & 0,1264 \\
\hline Pearson & 4,8104 & 3 & 0,1862 \\
\hline
\end{tabular}

Berdasarkan Tabel 8 dapat dijelaskan bahwa pada uji kelayakan model dengan peubah penjelas terlihat bahwa model kurang baik dengan nilai-p pada uji Pearson $0,1862>\alpha=5 \%$ dan nilai-p Deviance sebesar 0,1264> $\alpha=5 \%$. Dengan kata lain, peubah penjelas yang dimasukkan kedalam model, yaitu peubah status guru tidak memberikan pengaruh yang signifikan terhadap level jawaban guru pada soal kemampuan koneksi matematis antar topik.

\section{Pengaruh Status Guru Terhadap Kemampuan Koneksi Matematis Kedua}

Regresi logistik ordinal digunakan untuk mengkaji pengaruh status (guru kelas dan guru mapel) terhadap level jawaban guru pada kemampuan koneksi matematis dengan disiplin ilmu lain. Peubah respon (Y) pada penelitian ini adalah level jawaban guru yang terdiri dari 4 level. Dengan menggunakan prosedur Tabulate yang tersedia dalam SAS versi 9.0.0, dibuatlah tabel data level jawaban guru pada soal yang mengukur kemampuan koneksi matematis dengan disiplin ilmu lain sebagaimana tampak pada Tabel 9. 
Tabel 9. Level Jawaban Guru Pada

Kemampuan Koneksi Matematis

Dengan Disiplin Ilmu Lain

\begin{tabular}{cccccc}
\hline \multirow{2}{*}{ Status Guru } & \multicolumn{3}{c}{ Level Jawaban Guru } & To- \\
\cline { 2 - 5 } & 1 & 2 & 3 & 4 & tal \\
\hline Guru kelas & 3 & 11 & 8 & 17 & 39 \\
Guru mapel & 6 & 9 & 4 & 4 & 23 \\
\hline
\end{tabular}

Berdasarkan Tabel 9 tampak bahwa mayoritas guru kelas yang mengajar matematika pada kelas tinggi mampu menyelesaikan soal koneksi dengan disiplin ilmu lain pada level 4 sebanyak 17 guru. Sedangkan mayoritas guru mapel yang mengajar matematika pada kelas tinggi mampu menyelesaikan soal koneksi dengan disiplin ilmu lain pada level 2 sebanyak 9. Hasil analisis regresi logistik ordinal dengan menggunakan SAS versi 9.0.0 memperlihatkan bahwa model dengan peubah penjelas status guru lebih baik jika dibandingkan dengan model tanpa peubah penjelas. Model tersebut adalah model dengan peubah respon berupa level jawaban guru pada soal yang mengukur kemampuan koneksi matematis dengan disiplin ilmu lain. Hasil uji perbandingannya dapat dilihat pada Tabel 10.

Tabel 10. Hasil uji perbandingan pada model regresi logistik ordinal

\begin{tabular}{lccc}
\hline \multicolumn{1}{c}{ Model } & $\begin{array}{c}-2 \text { Log } \\
\text { Likelihood }\end{array}$ & $\begin{array}{c}\text { Devian- } \\
\text { ce }\end{array}$ & $\begin{array}{c}\text { Nilai- } \\
\mathrm{p}\end{array}$ \\
\hline $\begin{array}{l}\text { Model tanpa } \\
\text { peubah penjelas }\end{array}$ & 164,878 & & \\
\hline $\begin{array}{l}\text { Model dengan } \\
\text { peubah penjelas }\end{array}$ & 157,937 & 0,1243 & 0,9397 \\
\hline
\end{tabular}

Berdasarkan Tabel 10 dapat dijelaskan bahwa hasil perbandingan antara model tanpa peubah penjelas dengan model yang ditambahkan peubah penjelas. Nilai -2 Log Likelihood pada model dengan peubah sebesar 157,937 lebih kecil jika dibandingkan dengan nilai -2 Log Likelihood pada model tanpa peubah penjelas sebesar 164,878 , artinya model dengan peubah penjelas lebih baik daripada model tanpa peubah penjelas. Dengan kata lain, peubah penjelas yang dimasukkan kedalam model, yaitu peubah status guru memberikan pengaruh yang signifikan terhadap level jawaban guru.

Hasil pendugaan parameter regresi logistik ordinal dapat dilihat pada Tabel 11.

Tabel 11. Nilai dugaan parameter regresi logistik ordinal

\begin{tabular}{lrrr}
\hline & $\begin{array}{r}\text { Pendug } \\
\mathrm{a}\end{array}$ & $\begin{array}{r}\text { Galat } \\
\text { Baku }\end{array}$ & $\begin{array}{c}\text { Nilai- } \\
\mathrm{p}\end{array}$ \\
\hline Intercep & - & 0,436 & 0,012 \\
$\mathrm{t}$ & 1,095 & 1 & 0 \\
Intercep & 0,684 & 0,411 & 0,096 \\
$\mathrm{t}$ & 2 & 9 & 7 \\
Intercep & 1,550 & 0,447 & 0,000 \\
$\mathrm{t}$ & 1 & 2 & 5 \\
& - & 0,500 & 0,010 \\
status & 1,290 & 7 & 0 \\
& 4 & &
\end{tabular}

Berdasarkan Tabel 11 dapat dilihat bahwa peubah penjelas status guru kelas memberikan hasil yang signifikan terhadap kategori level jawaban guru pada soal kemampuan koneksi matematis dengan disiplin ilmu lain pada taraf $5 \%$.

\section{A. Interpretasi Hasil Output}


Hasil output SAS versi 9.0.0 memberikan informasi fungsi logit yang terbentuk adalah sebagai berikut :

$\mathrm{g}(\mathrm{x})=\log \left[\frac{P(Y \leq j)}{P(Y>j)}\right]=\alpha j+\beta x+\varepsilon$

$\mathrm{g}(\mathrm{x})=\alpha_{\mathrm{j}}-1,2904$ status(guru kelas)

- $\log \left[\frac{P(Y \leq 1)}{P(Y>1)}\right]=-1,0951-1,2904$ status(guru kelas)

- $\log \left[\frac{P(Y \leq 2)}{P(Y>2)}\right]=0,6842-1,2904$ status(guru kelas)

- $\log \left[\frac{P(Y \leq 3)}{P(Y>3)}\right]=1,5501-1,2904$

status(guru kelas)

Jika status guru berubah maka logit akan naik. Dengan demikian status guru antara guru kelas dan guru mapel berpengaruh terhadap peluang kumulatif level jawaban guru pada soal kemampuan koneksi matematis dengan disiplin ilmu lain. Hasil AIC memperlihatkan bahwa nilai AIC dengan intersep $(165,937)$ lebih kecil dari nilai AIC tanpa intersep $(170,878)$. Hal tersebut berarti model sudah baik.

Berdasarkan uji kelayakan model terlihat bahwa model sudah baik dengan nilai-p pada uji Pearson 0,9398 $>\alpha=5 \%$ dan nilai-p Deviance sebesar 0,9397 > $\alpha=$ $5 \%$. Sedangkan pada keseluruhan $\mathrm{G}=$ 6,9403 dengan nilai- $p=0,0084<\alpha=5 \%$ artinya model signifikan. Pada analisis effect dapat dilihat bahwa faktor status guru signifikan pada uji parsial dengan nilai- $p=0,0100<\alpha=5 \%$.
Berdasarkan model di atas dapat diketahui model peluang kumulatif untuk masing- masing kategori dengan rumus:

$P(Y \leq j)=\frac{\exp \left(\alpha_{\mathrm{j}}-1,2904 \text { status }_{\text {guru kelas) })}\right)}{1+\exp \left(\alpha_{\mathrm{j}}-1,2904 \text { status }_{\text {(guru kelas) }}\right)}$

Sebagai contoh, karena $\hat{\alpha}_{1}=$ 1,0951 dan $\hat{\alpha}_{2}=0,6842$ maka dugaan model peluang kumulatif untuk status guru kelas (status(guru kelas) $=1$ ) adalah:

$$
\begin{aligned}
P(Y \leq 1)= & \frac{\exp (-1,0951-1,2904(1)}{1+\exp (-1,0951-1,2904(1)}= \\
& 0,0843 \\
P(Y \leq 2)= & \frac{\exp (0,6842-1,2904(1)}{1+\exp (0,6842-1,2904(1)}= \\
& 0,3529
\end{aligned}
$$

Sehingga didapatkan dugaan model peluang kumulatif level jawaban guru untuk masing-masing status guru sebagaimana disajikan pada Tabel 12 .

Tabel 12. Dugaan model peluang kumulatif level jawaban guru untuk masing-masing status guru

\begin{tabular}{lcc}
\hline & $\begin{array}{c}\text { Status } \\
\text { guru kelas }\end{array}$ & $\begin{array}{c}\text { Status guru } \\
\text { mapel }\end{array}$ \\
\hline $\mathrm{P}(\mathrm{Y}<=1)$ & 0,0843 & 0,2507 \\
$\mathrm{P}(\mathrm{Y}<=2)$ & 0,3529 & 0,6646 \\
$\mathrm{P}(\mathrm{Y}<=3)$ & 0,5645 & 0,8249 \\
$\mathrm{P}(\mathrm{Y}<=4)$ & 1 & 1 \\
\hline
\end{tabular}

Sedangkan peluang untuk masingmasing kategori respon adalah selisih dari peluan5g kumulatif. Sebagai contoh, peluang dugaan bahwa seorang guru dengan status guru kelas mampu menyelesaikan soal kemampuan koneksi matematis dengan disiplin ilmu lain mempunyai level jawaban pada level 3 adalah: 


$$
\begin{aligned}
\hat{\pi}_{3} & =\hat{P}(Y=3)=\hat{P}(Y \leq 3)-\hat{P}(Y \leq 2) \\
& =0,5645-0,3529=0,2116
\end{aligned}
$$

Secara lengkap peluang dugaan level jawaban guru menurut status guru untuk masing-masing kategori respon disajikan pada Tabel 13.

Tabel 13. Peluang dugaan level jawaban guru menurut status guru untuk masing-masing kategori respon

\begin{tabular}{lcc}
\multicolumn{2}{c}{ AdMathEdu | Vol.11 No.1 } & Juni 2021 \\
guru keıas & mapeı \\
\hline $\mathrm{P}(\mathrm{Y}=1)$ & 0,0843 & 0,2507 \\
$\mathrm{P}(\mathrm{Y}=2)$ & 0,2686 & 0,4139 \\
$\mathrm{P}(\mathrm{Y}=3)$ & 0,2116 & 0,1603 \\
$\mathrm{P}(\mathrm{Y}=4)$ & 0,4355 & 0,1751 \\
\hline
\end{tabular}

Berdasarkan tabel tersebut dapat diperoleh informasi bahwa peluang dugaan bahwa seorang guru kelas mampu menyelesaikan soal kemampuan koneksi matematis dengan disiplin ilmu lain pada level paling tinggi (level 4) adalah sebesar $43,55 \%$. Sedangkan peluang dugaan bahwa seorang guru mapel mampu menyelesaikan soal kemampuan koneksi matematis dengan disiplin ilmu lain pada level paling tinggi (level 4) adalah sebesar $17,51 \%$.

\section{B. Interpretasi Koefisien}

Interpretasi koefisien untuk model regresi logistik ordinal dapat dilakuan dengan menggunakan nilai rasio oddsnya. Nilai rasio odds beserta selang kepercayaannya dapat dilihat pada Tabel 14.

Tabel 14. Rasio odds model regresi

\begin{tabular}{|c|c|c|c|}
\hline \multirow[t]{2}{*}{ Pengaruh } & \multirow{2}{*}{$\begin{array}{c}\text { Penduga } \\
\text { Rasio } \\
\text { Odds }\end{array}$} & \multicolumn{2}{|c|}{$\begin{array}{c}\text { SK 95\% Wald } \\
\text { bagi Rasio } \\
\text { Odds }\end{array}$} \\
\hline & & Lower & Upper \\
\hline $\begin{array}{l}\text { Status } \\
\text { guru }\end{array}$ & & & \\
\hline $\begin{array}{l}\text { kelas vs } \\
\text { guru } \\
\text { mapel }\end{array}$ & 0,275 & 0,103 & 0,734 \\
\hline
\end{tabular}
logistik ordinal

Kemampuan...(Ari)

bahwa besarnya penduga rasio odds sebesar 0,275. Penduga odds bahwa jawaban guru kelas pada arah jawaban level rendah daripada arah jawaban level tinggi sebesar 0,275 kali penduga odds untuk guru mapel. Dengan demikian, jawaban guru kelas pada level rendah lebih sedikit jika dibandingkan jawaban guru mapel. Selanjutnya, berdasarkan selang kepercayaan $95 \%$ dari nilai rasio odds, dapat dijelaskan bahwa guru yang berstatus guru kelas mempunyai peluang lebih kecil (sebesar 0,103 - 0,734 kali), jika dibandingkan dengan guru berstatus guru mapel untuk menjawab pada level rendah, pada soal yang mengukur kemampuan koneksi matematis dengan disiplin ilmu lain.

\section{Pengaruh Status Guru Terhadap Kemampuan Koneksi Ketiga}

Regresi logistik ordinal digunakan untuk mengkaji pengaruh status (guru kelas dan guru mapel) terhadap level jawaban guru pada kemampuan koneksi 
matematis dengan dunia nyata atau kehidupan sehari-hari. Peubah respon (Y) pada penelitian ini adalah level jawaban guru yang terdiri dari 4 level. Dengan menggunakan prosedur Tabulate yang tersedia dalam SAS versi 9.0.0, dibuatlah tabel data level jawaban guru pada soal yang mengukur kemampuan koneksi matematis dengan dunia nyata atau kehidupan sehari-hari sebagaimana tampak pada Tabel 15.

Tabel 15. Level Jawaban Guru Pada Kemampuan Koneksi Matematis Dengan Dunia Nyata Atau Kehidupan Sehari-hari

\begin{tabular}{cccccc}
\hline $\begin{array}{c}\text { Status } \\
\text { Guru }\end{array}$ & \multicolumn{3}{c}{ Level Jawaban Guru } & To- \\
\cline { 2 - 5 } & 1 & 2 & 3 & 4 & tal \\
\hline $\begin{array}{c}\text { Guru kelas } \\
\text { Guru }\end{array}$ & 0 & 9 & 8 & 22 & 39 \\
mapel & 0 & 4 & 9 & 10 & 23 \\
\hline
\end{tabular}

\section{Berdasarkan Tabel 15 tampak}

bahwa secara umum kemampuan koneksi matematis dengan dunia nyata atau kehidupan sehari-hari lebih baik daripada dua kemampuan koneksi matematis sebelumnya. Tampak bahwa tidak ada satu pun guru (baik guru mapel maupun guru kelas) yang memiliki level satu pada jawaban mereka. Mayoritas guru (baik guru kelas maupun guru mapel) mampu mencapai level jawaban 4 (jawaban lengkap).

Hasil uji kelayakan model pada analisis regresi logistik ordinal dengan menggunakan SAS versi 9.0.0 dapat dilihat pada Tabel 16.
Tabel 16. Hasil uji kelayakan model dengan peubah penjelas

\begin{tabular}{lccc}
\hline Kriteria & Nilai & Dr & Nilai-p \\
\hline Deviance & 2,4682 & 2 & 0,2911 \\
\hline Pearson & 2,5207 & 2 & 0,2835 \\
\hline
\end{tabular}

Berdasarkan Tabel 16 dapat dijelaskan bahwa pada uji kelayakan model dengan peubah penjelas terlihat bahwa model kurang baik dengan nilai-p pada uji Pearson 0,2911 > $\alpha=5 \%$ dan nilai-p Deviance sebesar 0,2835> $\alpha=5 \%$. Dengan kata lain, peubah penjelas yang dimasukkan ke dalam model, yaitu peubah status guru tidak memberikan pengaruh yang signifikan terhadap level jawaban guru pada soal kemampuan koneksi matematis dengan dunia nyata atau kehidupan sehari-hari.

\section{Kesimpulan}

Berdasarkan hasil penelitian dan pembahasan dapat disimpulkan bahwa: secara umum, kemampuan koneksi matematis dengan dunia nyata atau kehidupan sehari-hari lebih baik jika dibandingkan dengan kemampuan koneksi matematis dengan disiplin ilmu lain, dan kemampuan koneksi matematis dengan disiplin ilmu lain lebih baik jika dibandingkan dengan kemampuan koneksi matematis antar topik. Hal tersebut tampak dari persentase banyaknya mahasiswa yang mampu menjawab dengan lengkap (level 4) pada masing-masing kemampuan koneksi matematis tersebut. Selanjutnya, apabila dilihat berdasarkan status guru yaitu guru kelas dan guru mapel ditemukan 
perbedaan yang sangat mencolok terletak pada kemampuan koneksi matematis dengan disiplin ilmu lain. Pada kemampuan koneksi tersebut hampir separuh $(43,6 \%)$ guru kelas mampu menjawab pada level tertinggi (level 4). Jumlah yang jauh lebih banyak jika dibandingkan dengan banyaknya guru mapel yang mampu menjawab pada level tertinggi (level 4) hanya kurang dari seperlimanya saja $(17,4 \%)$.

Peubah penjelas yang dimasukkan kedalam model, yaitu peubah status guru tidak memberikan pengaruh yang signifikan terhadap level jawaban guru pada soal kemampuan koneksi matematis antar topik dan pada soal kemampuan koneksi matematis dengan dunia nyata atau kehidupan sehari-hari. Namun peubah penjelas status guru memberikan pengaruh yang signifikan terhadap level jawaban guru pada soal kemampuan koneksi matematis dengan disiplin ilmu lain. Peluang dugaan bahwa seorang guru kelas mampu menyelesaikan soal kemampuan koneksi matematis dengan disiplin ilmu lain pada level paling tinggi (level 4) adalah sebesar 43,55\%. Sedangkan peluang dugaan bahwa seorang guru mapel mampu menyelesaikan soal kemampuan koneksi matematis dengan disiplin ilmu lain pada level paling tinggi (level 4) adalah sebesar $17,51 \%$.

Berdasarkan hasil analisis regresi logistik ordinal diperoleh besar penduga rasio odds sebesar 0,275. Penduga odds bahwa jawaban guru kelas pada arah jawaban level rendah daripada arah jawaban level tinggi sebesar 0,275 kali penduga odds untuk guru mapel. Dengan demikian, jawaban guru kelas pada level rendah lebih sedikit jika dibandingkan jawaban guru mapel. Selanjutnya, berdasarkan selang kepercayaan 95\% dari nilai rasio odds, dapat dijelaskan bahwa guru yang berstatus guru kelas mempunyai peluang lebih kecil (sebesar 0,103 - 0,734 kali), jika dibandingkan dengan guru berstatus guru mapel untuk menjawab pada level rendah, pada soal yang mengukur kemampuan koneksi matematis dengan disiplin ilmu lain.

\section{Ucapan Terimakasih}

Ucapan terima kasih disampaikan kepada Direktorat Jenderal Pendidikan Islam Kementerian Agama Republik Indonesia selaku penyandang dana penelitian ini. Naskah artikel ini merupakan bagian dari laporan penelitian yang dibiayai oleh BOPTN Penelitian pada Perguruan Tinggi Keagamaan Islam tahun 2018.

\section{Pustaka}

Ahmad Nizar Rangkuti. 2017. Kesiapan Guru Matematika Dalam Menyongsong Masyarakat Ekonomi Asean (MEA). Prosiding SI MaNIs (Seminar Nasional Integrasi Matematika dan Nilai Islami) Vol.1, No.1, Juli 2017, Hal. 649-654 pISSN: 2580-4596; e-ISSN: 2580460X 324-13-1079-1-1020180205.pdf

Andi Gusmaulia Eka Putri. 2018. Kemampuan Koneksi Matematika : 
Why and How? Seminar Nasional Matematika dan Pendidikan Matematika (sendika) 2018 Program Studi Pendidikan Matematika Universitas Muhammadiyah Purworejo.

Agresti, A. 2007. An Introduction to Categorical Data Analysis. John Wiley \& sons Inc.

Agresti, A. 2002. Categorical Data Analysis Second Edition. New Jersey : John

[Mendikbud] Kementerian Pendidikan dan Kebudayaan. 2013. Salinan Lampiran Peraturan Menteri Pendidikan dan Kebudayaan Nomor 67 Tahun 2013 Tentang Kerangka Dasar dan Struktur Kurikulum Sekolah Dasar/ Madrasah Ibtidaiyah.

[NCTM] National Council of Teachers of Mathematic. 2000. Principle and Standards for School Mathematic 